Vieira et al., Revista Brasileira de Higiene e Sanidade Animal, v.11, n.1, p. 104-108, jan-mar, 2017

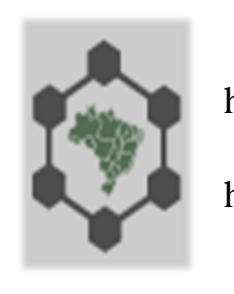

http://dx.doi.org/10.5935/1981-2965.20170011

Relato de Caso

http://www.higieneanimal.ufc.br

\title{
Complete Atlanto-axial malformation in a horse. Case report
}

\author{
Malformação atlantoaxial completa em equin. Relato de Caso
}

\begin{abstract}
Eloisa Helena Mendes Vieira ${ }^{1}$, Karoliny Farias Castelo Branco ${ }^{2}$, Hiara Marques Meneses ${ }^{3}$, Ingrid Barbosa de Mendonça ${ }^{4}$, Elzania Sales Pereira ${ }^{5}$, Carla Renata Figueiredo Gadelha ${ }^{6}$, Gabrimar Araújo Martins $^{7}$, Ana Cláudia Nascimento Campos ${ }^{8}$
\end{abstract}

\begin{abstract}
The occipitoatlantoaxial junction allows for free movement of the head. Anomalies of the craniovertebral junction are mentioned as defects in this joint and involve different degrees of fusion of the skull and atlas, as well as of the atlas with the axis. The occipitoatlantoaxial congenital malformations are recognized in humans, horses, sheep, cattle, lions, camels, goats and dogs. This study illustrates the rare case of a merger between the first and second vertebrae of the cervical equine spine. The skeleton of a 10 -year-old Quarter Horse racehorse was donated to the Federal University of Ceará. The owner reported that when the hose was alive, the animal showed resistance when turning its head to the right side, although movement to the left side was apparently normal. This peculiarity was attributed to behavioral problems. However, in this case, the Atlanto-axial malformation was found. This malformation is a complete fusion of the odontoid process of the axis with the ventral arch of the atlas and also the bilateral fusion of the axis with the lateral mass of the atlas. This merger generated a slight twist of the complex to the left side, but without neurological complications. This report is important not only because of the rarity of the vertebral malformation, but because the animal lived for 10 years without showing symptoms of any kind.
\end{abstract}

Keywords: cervical vertebrae, sport, merger.

Resumo: A junção occipitoatlantoaxial é o que permite o movimento livre da cabeça. As anomalias da junção craniovertebral são mencionadas como malformações nesta articulação e envolvem diferentes graus de fusão do atlas ao crânio ou do atlas com o axis. As malformações congênitas occipitoatlantoaxial são reconhecidas em humanos, cavalos, ovinos, bovinos, leões, camelo, caprinos e em cães. Relata-se, neste estudo, um caso raro de fusão entre a primeira e a segunda vértebra da coluna cervical de equino. $\mathrm{O}$ esqueleto de um equino de dez anos de idade, da raça Quarto de milha, foi doado à Universidade Federal do Ceará. O proprietário relatou que, quando estava vivo, o animal apresentava resistência ao virar a cabeça para o lado direito, embora o movimento para o lado esquerdo fosse, aparentemente, normal. Esta peculiaridade foi atribuída a problemas comportamentais. $\mathrm{Na}$ realidade, foi constatado um caso de malformação atlantoaxial, isto é, fusão completa do processo odontoide do axis com o arco ventral do atlas e, ainda, fusão bilateral do axis com as massas laterais do atlas. Esta fusão gerou uma leve torção desse complexo para o lado esquerdo, porém, sem complicações neurológicas. O presente relato tem importância não só pela raridade da malformação vertebral, mas pelo fato do animal ter vivido por dez anos em plena atividade sem apresentar sintomatologia de qualquer ordem.

Palavras-chave: vértebras cervicais, esporte, fusão.

Recebido em 20.12.2016. Aceito em 28.03.2017

Autor para correspondência. E. Mail: gabrimarm@gmail.com

${ }^{1}$ Universidade Federal do Ceará. ello.mendes@ hotmail.com

${ }^{2}$ Universidade Federal do Ceará. karolinyfarias@gmail.com

${ }^{3}$ Universidade Federal do Ceará. hiarameneses@ gmail.com

${ }^{4}$ Universidade Federal do Ceará. ibmzoo@ outlook.com 
${ }^{5}$ Professora Dra. da Universidade Federal do Ceará. elzania@ hotmail.com

${ }^{6}$ Professora Dra. da Universidade Federal do Ceará. crgadelha@ yahoo.com.br

${ }^{7}$ Professor Dr. da Universidade Federal do Ceará. gabrimarm@gmail.com

${ }^{8}$ Professora Dra. da Universidade Federal do Ceará. acncampos11@ gmail.com

\section{Introduction}

The first vertebrae of the cervical spine are particularly modified to allow for free movement of the head, because are the joints of the occipital condyles with the atlas that allow movements of dorsoventral bending and atlas with the axis that allow lateral rotation (DYCE et al., 2004). However, when an abnormality occurs between these vertebrae, the head joint is compromised, as is the neck joint.

Anomalies of the craniovertebral junction are mentioned as occipitoatlantoaxial malformations and involve varying degrees of symmetrical or asymmetrical mergers, unilaterally or bilaterally of the atlas to the skull or the atlas with the axis. The occipitoatlantoaxial congenital malformations are recognized in humans (Cave, 1930) and in a few species of animals. In horses, the occipitoatlantoaxial malformation is described as affecting the skull and cranial cervical vertebrae (MAYHEW et al, 1978; VIU et al., 2010).

Some authors have described other congenital or developmental disorders that may affect the cervical spine of horses, such as osteochondrosis dissecans and instability or poor alignment of the cranial vertebral column (VIU et al., 2010). Cases of merger, either total or partial, of the cervical vertebrae have been well-described in humans. One such case was described by Cave (1930), called Klippel-Feil syndrome, which involves the fusion of the atlas with the axis. It is an extremely rare anomaly, possibly the most rare of all of the various manifestations of irregular segmentations that affect the spine. Cave classified this anomaly into three groups: cases with fusion only of the odontoid process with the ventral arch of the atlas, cases with complete bilateral fusion of the atlas and axis, with or without attempts to assimilate the first vertebra with the second, and cases with a unilateral merger where the axis is fused only in one of the lateral masses of the atlas.

After consulting the literature concerning the occipitoatlantoaxial malformation in horses, it is noted that the descriptions of cases involving mergers of the first cervical vertebrae are still scarce in Brazil. Thus, the goal of this study was to report a rare case of a merger between the first and second vertebrae of the cervical spine of a horse.

\section{Case report}

The skeleton of a 10-year-old Quarter Horse racehorse that died due abdominal cramps was donated to the Anatomy Laboratory of the Federal University of Ceara. The owner said that when the animal was alive, it showed resistance when turning its head to the right side, although movement to the left side was apparently normal.

This peculiarity was not assigned to any anatomical anomaly but to behavioral problems. However, the animal appeared to be in a state of soft constant torticollis on the left side. Although the animal was used for practicing sport, this 
disorder did not damage its training routine, considering that it was a horse used in rodeos. In general, in this competition, the horses running on the right side of the cattle are left with the head turned to the left, and the horses that run on the left turn the head to the right. In the case of the animal studied, the owner reported that it ran with his head visibly facing forward.

No investigation was carried out to understand the peculiar behavior of the horse. After evaluating the skeleton, it was verified that there was a complete fusion of the first cervical vertebrae, i.e. a case of Atlanto-axial malformation (AAM). Thus, in the pathological inspection, a complete merger of the odontoid process of the axis was found with the ventral arch of the atlas, in addition to bilateral fusion of the axis with the lateral mass of the atlas (Figure 1A).

This fusion generated a slight twist of the complex to the left side (Figure 1B), which may have given the owner the impression that the animal's head normally flexed to this side.

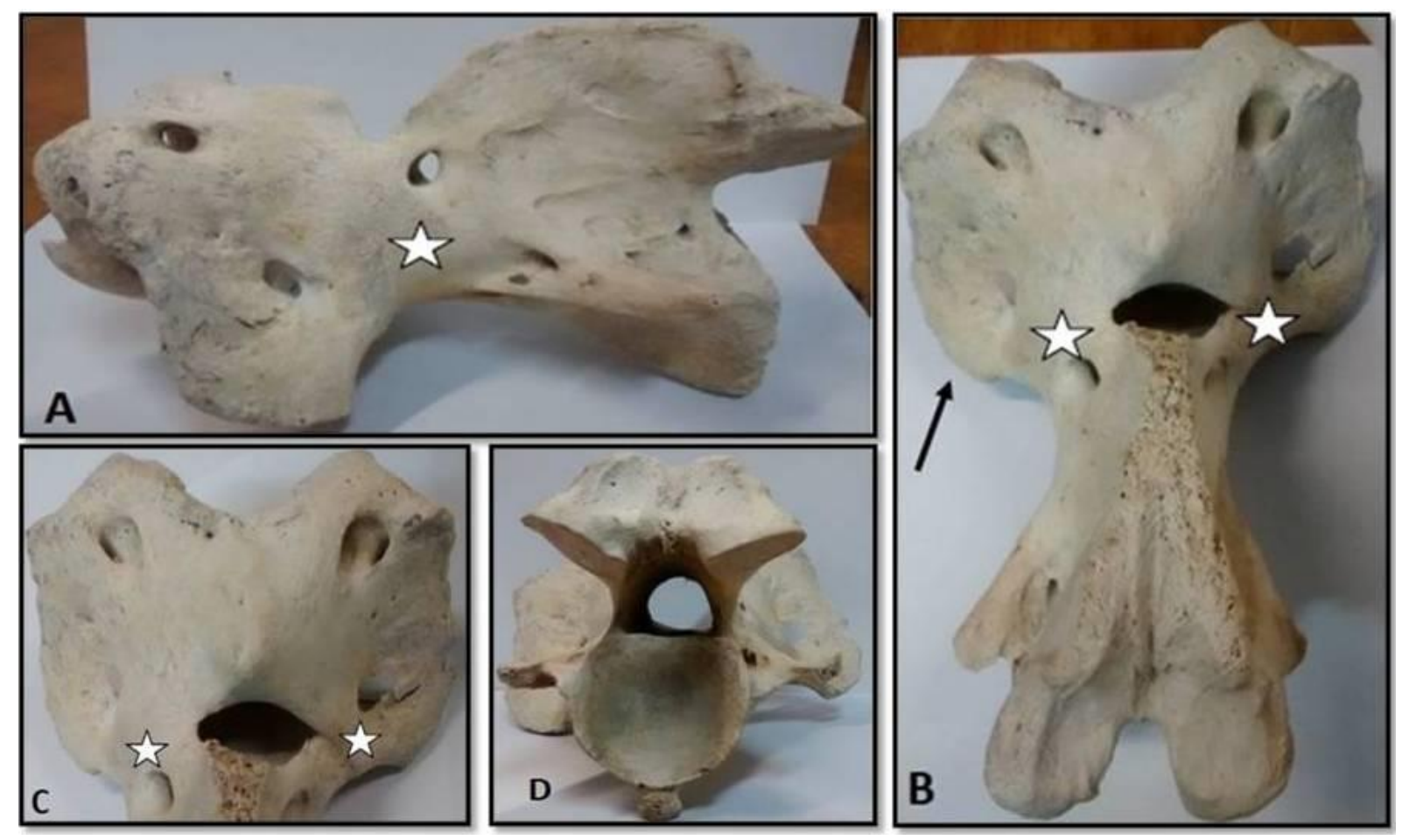

Figure 1. Complete bilateral fusion of the atlas and axis. A - The left lateral view of complete atlanto-axial malformation (CAAM). B - The dorsal view of CAAM showing the left lateral inclination (arrow). The start shows the fusion bone mass. C - Dorsal view of the atlas. D - Caudal views of the axis.

\section{Discussion}

In most studied cases, the animals had neurological clinical signs, which were soon detected at birth or that developed in the first weeks or months of life (MAYHEW et al., 1978).
However, Gomez et al. (2007) reported a case in which nervous symptoms appeared only when the mare was five years and nine months old. The authors attributed the neurological disorders to progressive joint deterioration. 
However, in this study, the owner did not report any apparent neurological problem. The only reported issue was that the animal stubbornly refused to obey the command to turn the head to the right.

Therefore, we can say that the animal did not suffer any compression of the spinal cord that could trigger neurological symptoms. Figures 1C and D illustrate the absence of narrowing of the spinal canal.

In horses, occipitoatlantoaxiais malformations were classified into one of three categories: 1) atlas occipitalization with atlantalization of the axis in Arabian horses, 2) congenital malformation asymmetrical occipitoatlantoaxial, and 3) asymmetric atlantooccipital fusion (ROSENSTEIN et al., 2000). The anomaly of this report does not fall into any of these categories since the AAM was symmetrical and complete. The occipitoatlantoaxial malformation in this species is attributed to abnormal development in the caudal region of the occipital bone and the cranial region of the cervical sclerotomes (Wilson et al., 1985); however, it is still not clear the cause of this abnormal development. In some situations, the cause of bad spinal alignment is multifactorial and includes eating disorders, trauma, infections and genetic factors (WITTE et al., 2005). However, this study reports a case of complete fusion between the atlas and axis, an extremely rare situation (Cave, 1930) that is rarely reported in domestic animals. In humans, this condition is known as Klippel-Feil syndrome, indicating a congenital merger of two or more cervical vertebrae, which may be associated with many other disorders (PARK et al., 2006). Klippel-Feil syndrome is relatively common, but the fusion of the odontoid process with the atlas is a very rare find (PÉREZ-VALLINA et al., 2002). The genetic basis for this syndrome is unclear, but some authors have suggested that the anomaly is due to a faulty segmentation of mesodermal somites between the third and seventh week of intrauterine life (VOLTOLINI DE AZAMBUJA et al., 2010). In cases where the atlas merges with the axis, it is difficult to determine for sure whether there was a failure in the cleavage of the Atlanto-axial segment or if these vertebrae, which were previously separate, underwent a subsequent merger (CAVE, 1930). In this study, the finding suggests that the merger occurred during fetal development, although it is impossible to define the exact moment. According to Schmidt et al. (1993), the rarity of a lesion with no epidemiological pattern of teratogenic disease in the herd suggests a skeletal congenital defect. So to the authors, this type of defect can occur at any time between the formation of early cartilage and the differentiation of ossification centers in the axial skeleton. This report is important not only because of the rarity of the vertebral malformation, but because the animal lived for 10 years without showing symptoms of any kind.

\section{Conclusion}

The evaluation of the horse's skeleton showed that there was a complete fusion of the first cervical vertebrae, a case of Atlanto-axial malformation. This merger generated a slight twist of the complex to the left side, but without neurological complications.

\section{Acknowledgments}

Appreciation is given to the owner of the horse and author of this article, Karoliny Farias 
Vieira et al., Revista Brasileira de Higiene e Sanidade Animal, v.11, n.1, p. 104-108, jan-mar, 2017

Castelo Branco, who donated the skeleton as study material in the discipline of animal anatomy at the Federal University of Ceará.

\section{References}

1.CAVE, A.J.E. On fusion of the atlas and axis vertebrae. Journal of Anatomy, Austin, v. 64, n. 3, p. 337-343, 1930.

2. DYCE, K.M.; WENSING, C.J.G.; SACK, W. O. Tratado de Anatomia Veterinária. $3^{\circ}$ Ed. Rio de Janeiro: Elsevier Brasil, 2004. 821 p.

3. GÓMEZ S.; GÓMEZ M.A.; BUENDÍA A.J. Malformación occipitoatlantoaxial congénita en uma yegua pura raza española. Anales de Veterinaria de Murcia, Murcia, v. 23, p. 87-90, 2007.

4. MAYHEW, I.G.; WATSON, A.G.; HEISSAN, J. A. Congenital occipitoatlantoaxial malformations in the horse. Equine Veterinary Journal, Cambridgeshire, v. 10, n. 2, p. 103-113, 1978.

5. PARK, S.Y.; RYU, K.N.; PARK, J.S.; SUK, K. S.; HAN, M.Y. Unilateral fusion of the odontoid process with the atlas in Klippel-Feil syndrome: $A$ case report. Journal of the Korean Radiological Society, Mapo-gu, v. 55, n. 1, p. 39-42, 2006.

6. PÉREZ-VALLINA, J.R.; RIAÑO-GALÁN, I.; COBO-RUISÁNCHEZ, A.; OREJASRODRIGUEZ-ARANGO, G.; LÓPEZ-MUÑIZ, C.; FERNÁNDEZ-MARTÍNEZ, J.M. Congenital anomaly of craniovertebral junction: Atlas-dens fusion with $\mathrm{C} 1$ anterior arch cleft. Journal of Spinal Disorders \& Techniques, Philadelphia, v. 15, n. 1, p. 84-87, 2002.

7. ROSENSTEIN, D.S.; SCHOTT, H.C.; STICKLE, R.L. Imaging diagnosis: Occipitoatlantoaxial malformation in a miniature horse foal. Veterinary Radiology \& Ultrasound, Clemson, v. 41, n. 2, p. 218-219, 2000.

8. SCHMIDT, S.P.; FORSYTHE, W.B.; COWGILL, H.M.; MYERS, R.K. A case of congenital occipitoatlantoaxial malformation (OAAM) in a lamb. Journal of Veterinary Diagnostic Investigation, Visalia, v. 5, n. 3, p. 458-462, 1993.
9. VIU, J.; ARMENGOU, L.; JOSE-CUNILLERAS, E.; CESARINI, C.; PUMAROLA, M.; MONREAL, L. Cranioencephalic malformation with Atlanto-occipital luxation in an Andalusian neonate foal. Journal of Veterinary Internal Medicine, Columbus, v. 24, n. 3, p. 639-642, 2010.

10. VOLTOLINI DE AZAMBUJA, H.; VOLTOLINI DE AZAMBUJA, W.; MENEGAZ ZANATTA, G. Síndrome de Klippel-Feil: Relato de caso e posssibilidades ortodônticoortopédicas. Revista da Faculdade de Odontologia, Passo Fundo, v. 8, n. 2, p. 15-19, 2010.

11. WILSON, W. D.; HUGHES, S. J.; GHOSHAL, N. G.; MCNEEL, S. V. Occipitoatlantoaxial malformation in two nonArabian horses. Journal of the American Veterinary Medical Association, Schaumburg, v. 187, n. 1, p. 36-40, 1985.

12. WITTE, S.; ALEXANDER, K.; BUCELLATO, M.; SOFALY, C.; FIFE, W.; HINCHCLIFF, K. W. Congenital Atlanto-axial luxation associated with malformation of the dens axis in a Quarter Horse foal. Equine Veterinary Education, Cambridgeshire, v. 17, n. 4, p. 175178, 2005. 